\title{
PENGEMBANGAN LKPD INKUIRI BERPENDEKATAN NESTED UNTUK MELATIHKAN KETERAMPILAN PROSES SAINS PADA MATERI LAJU REAKSI
}

\author{
Mustainah Isnaini ${ }^{1}$, Bertha Yonata ${ }^{{ }^{*}}$ \\ ${ }^{12}$ Program Studi Pendidikan Kimia, Universitas Negeri Surabaya. JalanKetintang Gedung D1, \\ Surabaya 60231, Indonesia. \\ *Coresspending Author. E-mail: berthayonata@unesa.ac.id
}

Received: 30 Desember 2020 Accepted: 12 Juli 2021

doi: $10.29303 /$ cep.v4i2.2334

Published: 14 Agustus 2021

\begin{abstract}
Abstrak
Penelitian ini bertujuan untuk mengetahui kelayakan LKPD inkuiri berpendekatan nested dalam rangka melatih keterapilan proses sains siswa. Metode yang digunakan adalah desain pengebangan 4-D dilakukan sampai tahap pengembangan. Uji coba LKPD dibatasi pada 12 siswa kelas XI MIPA SMAN 1 Sidayu yang belum mendapatkan materi laju reaksi. Instrumen yang digunakan terdiri dari lembar tes (pretest dan posttest) keterampilan proses sains (KPS), tes ranah pengetahuan,telaah, validasi, aktivitas dan angket respon. Pengembangan LKPD ini dinyatakan layak digunakan karena hasil penelitian diperoleh nilai validasi $\geq 61 \%$ dan nilai yang diperoleh siswa $\geq 75$ sesuai kriteria ketuntasan minimal sekolah. Presentase validasi kriteria isi $86,3 \%$, kesesuaian dengan inkuiri $80 \%$, kesesuaian dengan komponen keterampilan proses sains $80 \%$, bahasa $90,7 \%$, dan grafis $90,7 \%$ kategori valid secara teoritis dan empiris. Respon peserta didik menunjukkan respon positif dengan persen rata-rata $93 \%$ kriteria sangat merespon. LKPD yang dikembangkan efektif digunakan karena tes keterampilan proses sains (KPS) diperoleh n-gain skor sebesar 0,84 kategori sangat tinggi. Hal tersebut didukung dengan hasil tes pengetahuan diperoleh nilai rata-rata yang diperoleh $\geq 75$ yang berarti sudah memenuhi kriteria ketuntasan minimal sekolah.
\end{abstract}

Kata Kunci: LKPD, inkuiri, nested, keterapilan proses sains, laju reaksi

\section{The LKPD Inquiry Development of Nested Approach to Training Science Process Skills in Reaction Rate Material}

\begin{abstract}
This research aims to determine the feasibility of an inquiry LKPD with a nested approach in order to train students' science process skills. This research method used a 4-D block design which wasdone only until the develop stage. The LKPD trial was limited to 12 students of class XI MIPA SMAN 1 Sidayu who had not received material on reaction rates. The instruments used consisted of test sheets (pretest and posttest) for science process skills, domain knowledge tests, study sheets, validations, activity and response questionnaires. The results showed that the LKPD which is developed was feasible based on the validation value $\geq 61 \%$ and the values which are obtained bystudents $\geq 75$ according to the minimum completeness criteria for school. The percentage of content criteria validation was $86.3 \%$, conformity with inquiry was $80 \%$, conformity with science process skills components was $80 \%$, language was $90.7 \%$, and graphics were $90.7 \%$ theoretically and empirically valid. The response of students showed a positive response with an average percentage of $93 \%$ very responding criteria. The developed LKPD was effectively used because the results of the science process skills test obtained an $n$-gain score of 0.84 in the very high category. Itwas supported by the results of the knowledge test obtained by an average value of $\geq 75$, which meant that it hadfulfilled the minimum completeness criteria for school.
\end{abstract}

Keywords: LKPD, inquiry, nested, skills of science process, rate of reaction. 


\section{Chemistry Education Practice, 4 (2), 2021 - 154}

Isnaini, Yonata

\section{PENDAHULUAN}

Pemerintah Republik Indonesia saat ini sedang menerapkan Kurikulum 2013, yang menekankan penerapan pendekatan scientific dimana pendekatan tersebut terdiri dari kegiatan mengamati, menanya, mengumpulkan data, mengasosiasi dan mengkomunikasikan, yang berisi keseimbangan antara pengembangan sikap, keterampilan dan pengetahuan (Sudarwan 2013). Berdasarkan kurikulum 2013 di atas, pembelajaran kimia harus dilaksanakan dengan melibatkan keterampilan dan penalaran siswa, sehingga siswa memperoleh pengetahuan secara utuh yaitu kimia sebagai proses (kerja ilmiah) dan produk (fakta-fakta, konsep-konsep, atau prinsipprinsip) (Ariani dkk., 2020; BNSP 2010).

Kimia merupakan suatu ilmu yang mempelajari tentang komposisi zat, struktur dan sifat suatu zat, transformasi zat, dinamika zat, dan energetika zat dengan melibatkan proses penalaran dan keterampilan (Depdiknas 2008). Oleh sebab itu, pembelajaran kimia tidak hanya memuat konsep-konsep perhitungan, melainkan melakukan eksperimen untuk memberikan pengalaman belajar secara langsung dan penerapan ilmu kimia dalam kehidupan seharihari (Permendikbud 2020). Munculnya kegiatan tersebut terdapat dalam beberapa materi kimia di sekolah, salah satunya laju reaksi.

Kompetensi dasar yang harus dicapai oleh siswa pada materi laju reaksi berdasarkan kurikulum 2013 saat ini adalah 3.4 Menjelaskan faktor-faktor yang mempengaruhi laju reaksi menggunakan teori tumbukan dan 4.5 Merancang, melaksanakan, dan menyimpulkan serta mempresentasikan hasil eksperimen faktorfaktor yang mempengaruhi laju reaksi dan urutan reaksi (Permendikbud 2020). Kompetensi dasar tersebut terlihat bahwa materi laju reaksi tidak hanya menekankan pada penguasaan konsep, tetapi juga membutuhkan pembuktian melalui eksperimen yang dapat dilakukan peserta didik dengan cara mengamati, menganalisis dan meyimpulkan secara mandiri percobaaan tersebut. Dalam hal ini lebih ditekankan adanya keterampilan proses dalam pembelajaran kimia. Pendekatan keterampilan proses sains merupakan pendekatan pembelajaran yang berorientasi kepada proses sains (Rustaman 2005).

Dengan mengembangkan keterampilan proses, siswa dapat menemukan fakta, menetapkan konsep, teori, dan sikap ilmiah, dan pada akhirnya memberikan dampak positif pada proses dan produk (Trianto 2012). Cleaf (1991) menyatakan bahwa inkuiri adalah salah satu pendekatan yang digunakan dalam kelas yang berorientasi proses. Model inkuiri sebagai proses mendefinisikan dan menyelidiki masalahmasalah, merumuskan hipotesis, merancang eksperimen, menemukan data, dan menggambarkan kesimpulan masalah tersebut (Arends 2012). Dapat disimpulkan bahwa model pembelajaran yang tepat untuk melatihkan keterampilan proses sains adalah inkuiri.

Model inkuiri memiliki kelemahan yakni mengharuskan siswa memiliki kesiapan mental, siswa harus memiliki pengetahuan awal agar proses pembelajaran dapat berjalan, dan harusmemiliki fasilitas untuk melakukan percobaan dalam menemukan konsep (Sanjaya 2012; Aftriani dkk., 2019). Namun disisi lain, siswa diharapkan mampu melakukan pengolahan serta penafsiran data, khususnya pengorganisasian (Permendikbud 2012). Oleh sebab itu, perlu adanya integrasi pembelajaran untuk pembelajaran yang lebih optimal.

Model pembelajaran terpadu yang memiliki potensi sesuai kelemahandari pembelajaran inkuiri adalah pembelajaranterpadu tipe Nested yang merupakan suatu keterampilan peserta didik untuk mengintegrasikan kurikulum ataupembelajaranagar mendapatkan suatu konsep ataukonsten dengan cara menyarang. Sejalan dengan itu, pembelajaran terpadu tipe Nestedmerupakanmodel pemebelajaran dengan memadukan keterampilan berpikir (thinking skill), keterampilan sosial(sosial skill), dan keterampilan mengorganisir(organizing skill). Keterampilan mengorganisir (organzing skills) diantaranya yakni membuat tabel dan grafik (Fogarty 1991).

Dalam menerapkan pembelajaran kimia yang efektif pada masa pandemi karena Covid-19 diperlukan media pembelajaran yang tepat. Berdasarkan wawancara salah satu guru kimia di SMAN 1 Sidayu, menyatakan bahwa media yang tepat digunakan adalah LKPD. Hal itu dirasa tepat karena pendistribusian LKPD tidak membutuhkan banyak kuota dan sinyal yang stabil dalam proses pembelajaran dilakukan secara online. Selain itu, siswa lebih aktif dalam memahami konsep dengan arahan guru dengan waktu yang lebih fleksibel.

Selain itu, untuk meningkatkan keterampilan proses sains diperlukan suatu bahan ajar yang dapat memudahkan guru dalam penyampaian informasi. Lembar kerja peserta didik (LKPD) merupakan salah satu bahan ajar yang dibutuhkan untuk digunakan sebagai 


\section{Chemistry Education Practice, 4 (2), 2021 - 155}

Isnaini, Yonata

pedoman bagi peserta didik dalam melakukan eksperimen. Hasil penelitian Kurniawati et al. (2016) menunjukkan bahwa penerapan model pembelajaran inkuiri terbimbing yang dilengkapi LKPD dapat meningkatkan KPS peserta didik.

Berdasarkan uraian tersebut perlu diajukanpenelitian dengan judul pengembangan LKPD inkuiri berpendekatannested untuk melatihkan keterampilan proses sains (KPS) pada sub materi faktor yang mempengaruhi laju reaksi.

\section{METODE}

Jenis penelitian yang digunakan adalahpengembangan Research and Development (R \& D) dengan model 4-D yang meliputi Devine, Desaind, Develope dan Disseminate (Trianto 2012). Penelitian ini merupakan pengembangan Lembar Kerja Peserta Didik (LKPD) berorientasi inkuiri dalam melatihkan keterampilan proses sains (KPS) pada materi laju reaksi kelasXI SMA. Uji coba dilaksanakan pada peserta didik kelas XI MIPA SMAN 1 Sidayu yang dilakukan di semester ganjil tahun pembelajaran 2020/2021. Sasaran pada penelitian ini adalah LKPD yang dikembangkan. Metode penelitian ini menggunakan desain 4-D meliputi definisi, desain, pengembangan, dan diseminasi (Trianto 2012). Penelitian hanya dilakukan sampai tahap pengembangan, dan tahap diseminasi tidak dilakukan.

Sumber data diperoleh dari 15 peserta didik, validasi dan uji coba terbatas. Alat penelitian berupa lembar belajar, lembar verifikasi, lembar tes pengetahuan dan lembar tes keterampilan proses sains yang meliputi pretes dan postest, serta angket respon siswa dan lembar observasi aktivitas siswa yang digunakan untuk mengamati aktivitas siswa selama pelaksanaan eksperimen. Teknik pengumpulan data yang digunakan adalah tes, observasi aktivitas dan angket yang meliputi review atau telaah, verifikasi dan respon.

Uji kelayakan LKPD diperoleh dari nilai telaah dan validasi yang melibatkan dosen jurusan kimiaUNESA serta guru bidang studi kimia di SMA Negeri 1 Sidayu. Hasil telaah digunakan untuk menyempurnakan LKPD yang dikembangkan dan dianalisis secara deskriptif. Sedangkan hasil validasi dianalisis menggunakan metode deskriptif kualitatif melalui perhitungan presentase. Presentase yang dihasilkan diperoleh berdasarkan skala Likert yang disajikan melalui Tabel 1.
Tabel 1. Skala Likert

\begin{tabular}{cc}
\hline Pernyataan & Skor \\
\hline Tidak valid & 1 \\
Kurang valid & 2 \\
Cukup valid & 3 \\
Valid & 4 \\
Sangat valid & 5 \\
\hline
\end{tabular}

Sumber: (Riduwan 2013)

Rumus perhitungan yang digunakan untuk meperoleh presentase kelayakansebagai berikut: $\%$ Presentase $=\frac{\Sigma \text { skor yang diperoleh }}{\Sigma \text { skor maksimal }} \times 100 \%$ (Riduwan 2013)

Hasil presentase yang diperoleh $\geq 61 \%$. Menurut standar interpretasi skor, LKPD yang dikembangkan memenuhi standar isi, representasi atau penyajian, bahasa dan grafis, yang dinyatakan layak digunakan sebagai media pembelajaran.

Hasil angket respon dan aktivitas peserta didik dianalisis secara deskriptif kuantitatif. Presentase data yang diperoleh dari angket respon siswa beserta aktivitasnya diperoleh berdasarkan perhitungan skor skala Guttman yang disajikan pada Tabel 4.

Tabel 4. Interpretasi Skor

\begin{tabular}{ccc}
\hline Pertanyaan & Jawaban & Skor \\
\hline \multirow{2}{*}{ Positif } & Iya & 1 \\
& Tidak & 0 \\
Negatif & Iya & 0 \\
& Tidak & 1 \\
\hline
\end{tabular}

Sumber: (Riduwan 2013)

Berdasarkan skala Guttman, untuk memperoleh kelayakan dan kriterianya menggunakan rumus:

$$
\begin{gathered}
\% \text { respon siswa }=\frac{\Sigma \text { skor yang diperoleh }}{\Sigma \text { skor maksimal }} \times 100 \% \\
\% \text { aktivitas siswa }= \\
\frac{\Sigma \text { frekuensi aktivitas yang muncul }}{\Sigma \text { total frekuensi aktivitas }} \times 100 \%
\end{gathered}
$$

(Riduwan 2013)

Presentase respon peserta didik tersebut kemudian dikategori mengacu pada tabel 5.

Tabel 5. Kriteria respon peserta didik

\begin{tabular}{cc}
\hline Presentase & Kriteria \\
\hline $0 \%-20 \%$ & Tidak respon \\
$21 \%-40 \%$ & Kurang respon \\
$41 \%-60 \%$ & Cukup respon \\
$61 \%-80 \%$ & Respon \\
$81 \%-100 \%$ & Sangat respon \\
\hline
\end{tabular}

Sumber: (Riduwan 2013) 
Sedangkan untuk analisis data yang dihasilkan pada tes pengetahuan pada materi laju reaksi dihitung menggunakan rumus:

Hasil belajar $=\frac{\sum \text { skor yang diperoleh }}{\sum \text { skor maksimal }} \times 100 \%$

Sedangkan analisis hasil perhitungan dilakukan dengan menggunakan skor n-gain. Perbedaan pretest dan posttestseara rata-rata dihitung menggunakan rumus:

$\mathrm{n}$-gain $==\frac{\text { skor } \text { posttest-skor pretest }}{\text { skor maksimal-skor pretest }} \times 100 \%$

Skor n-gain yang diperoleh dipresentasikan sesuai Tabel 2.

Tabel 2. Kategori Skor N-gain

\begin{tabular}{cc}
\hline Skor N-gain & Kategori \\
\hline$\geq 0,7$ & Tinggi \\
$0,3 \leq \mathrm{g}<0,7$ & Medium \\
$0,0 \leq \mathrm{g}<0,3$ & Rendah \\
\hline
\end{tabular}

Sumber: (Riduwan 2013)

Peserta didik dikatakan menguasai materi jika skor hasil belajar $\geq 75$ sesuai dengan kriteria ketuntasan minimal sekolah. Hasil dari penilaian terhadap keterampilan proses sains dianalisis seara deskriptif. Komponen yang terlibat adalah merumuskan masalah, hipotesis, identifikasi variabel percobaan, menyajikan data, analisis data, dan menarik kesimpulan. Tiap-tiap komponen diperoleh hasildengan rumus skor $\mathrm{n}$ gain yang kemudian dikategori sesuai Tabel 3 .

Tabel 3. Interpretasi Skor

\begin{tabular}{cc}
\hline Presentase & Kategori \\
\hline $0-20$ & Sangat rendah \\
$21-40$ & Rendah \\
$41-60$ & Normal \\
$61-80$ & Tinggi \\
$81-100$ & Sangat Tinggi \\
\hline
\end{tabular}

Sumber: (Riduwan 2013)

Berdasarkan data yang diperoleh dari analisis tes KPS secara individu dianalisis dengan menggunakan skor n-gain. Peserta didik dikatakan menguasai keterampilan proses sains jika memperoleh hasil $\geq 75$. Nilai yang diperoleh telah memenuhi KKM sekolah.

\section{HASIL DAN PEMBAHASAN}

\section{Validitas LKPD}

Desain

pengembangan

LKPD

menggunakan 4-D. Penelitian ini dilakukan sampai pada tahap pengembangan saja. Berikut tahapan yang dilakukan:

Tahap Pendefinisian/Devine

Tujuan tahapan ini adalah untuk menentukan dan menetapkan persyaratan penyusunan LKPD. Kegiatan analisis dilakukan sesuai kebutuhan, meliputi analisis siswa, analisis tugas, analisis konsep, dan spesifikasi indikator.

Tahap Perencanaan/Design

Kegiatan yang dilakukan pada tahap ini adalah menyiapkan bahan, memilih menyusun format LKPD, kemudian merancang LKPD. Hasil dari kegiatan utama ini adalah Draft 1, kemudian konsultasi mendalam dengan dosen penelaah.

Berikut hasil akhir desain pengembangan LKPD pada sub materi faktor-faktor yang mempengaruhi laju reaksi:

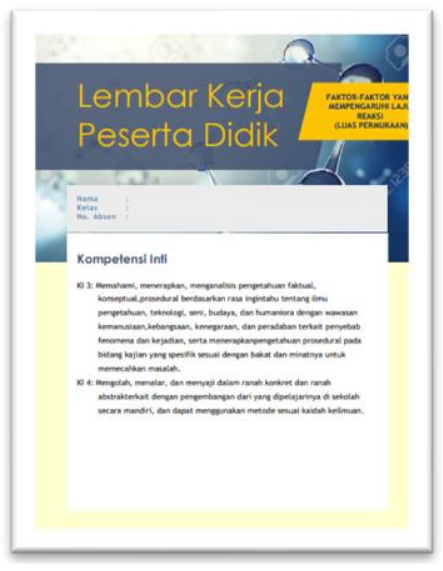

Gambar 1. Pemetaan KD

Gambar 1 merupakan halaman awal yang berisi pemetaan kompetensi dasar, kompetensi inti, indeks pencapaian kompetensi, dan tujuan pembelajaran.

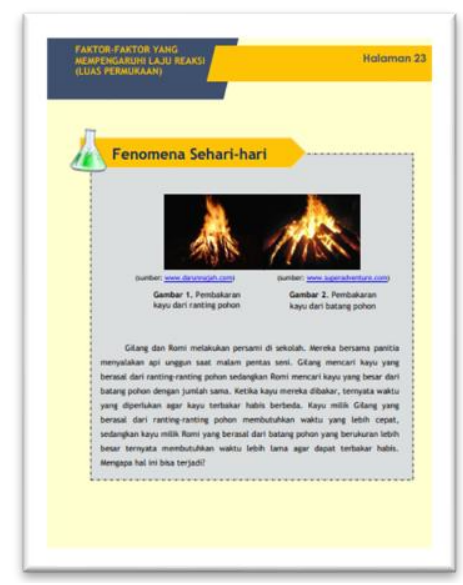

Gambar 2. Isi

Gambar 2 merupakan bagian isi. Pada bagian ini terdapat fenomena kehidupan sehari-hari yang berhubungan dengan pertanyaan pada tahapan keterampilan proses sains. 


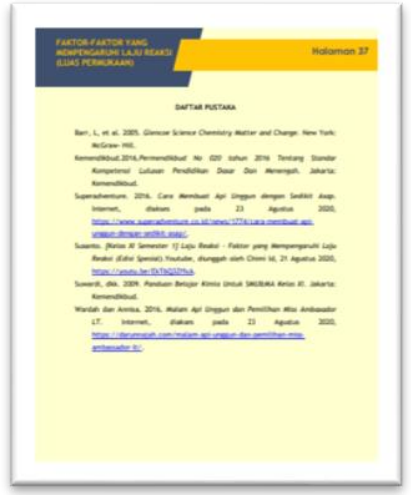

Gambar 3. Daftar Pustaka

Gambar 3 merupakan halaman akhir dari LKPD. Berisi daftar-daftar rujuka yang digunakan pada LKPD.

\section{Tahap Pengembangan/Develop}

Pengembangan ini bertujuan untuk menghasilkan produk berupa Lembar Kerja Siswa (LKPD) yang dapat digunakan sebagai bahan ajar agar lebih sempurna melalui modifikasi dan saran ahli.Pada tahap ini, proses yang dilakukan adalah telaah LKPD, validasi LKPD, kemudia melakukan uji coba LKPD terbatas.

Telaah pada penelitian ini dilakukan oleh dua orang dosen dari Departemen Kimia UNESA. Hasilnya berupa saran dan komentar untuk perbaikan LKPD yang dikembangkan. Saran dan komentar telaah antara lain, terdapat nomor pertanyaan yang lebih baik dibalik karena struktur pertanyaan yang termuat harus runtun dalam membimbing peserta didik dalam menemukan konsep. Hal ini sangat sesuai dengan model pembelajaran inkuiri terbimbing, dimana siswa dapat memperoleh bimbingan sesuai kebutuhan. Tahapan awal berupa pertanyaan pedoman untuk melakukan langkah berikutnya (Mulyasa 2011). LKPD mempunyai langkah kerja sistematis yang memungkinkan siswa belajar mandiri dalam memahami dan melaksanakan tugas (Depdiknas 2008).

Setelah dilakukan kalibrasi sesuai rekomendasi, dilakukan verifikasi atau validasi oleh seorang dosen kimia FMIPA Unesa dan dua guru kimia dari SMAN 1 Sidayu. Hasil verifikasi atau validasi berupa data keabsahan LKPD yang ditinjau dari validitas isi dan standar keabsahan struktural (meliputi bahasa, representasi dan grafik). Jika persentase hasil setiap kriteria $\geq 61 \%$, LKPD yang dikembangkan dinyatakan valid (Riduwan 2013). Persentase rata-rata validasi yang dihasilkan dipaparkan pada Tabel 7.
Tabel 7. Hasil Validasi

\begin{tabular}{lll}
\hline $\begin{array}{c}\text { Kriteria } \\
\text { yang Dinilai }\end{array}$ & $\begin{array}{c}\text { Presentase } \\
\text { Rata-rata }\end{array}$ & \multicolumn{1}{c}{ Kategori } \\
\hline Isi & $86,3 \%$ & Sangat valid \\
Kebahasaan & $90,7 \%$ & Sangat valid \\
Penyajian & $89,2 \%$ & Sangat valid \\
Kegrafisan & $90,7 \%$ & Sangat valid \\
\hline
\end{tabular}

Kelayakan kriteria isi mendapatkan presentase $86,3 \%$ dalam kategori sangat valid. Hal ini berarti LKPD telah memenuhi kriteria Sesuai dengan kelayakan isi BSNP termasuk materi memenuhi standar kemampuan (SK) dan kemampuan dasar (KD) yang ingin dicapai, tujuan pembelajaran jelas(BNSP 2010). LKPD yang dikembangkan memiliki kegiatan yang berupacontoh penerapan materi pada kehidupan yang biasa kita lakukan sehari-hari dan fenomena laboratorium. Kegiatan tersebut memuat materi faktor yang mempengaruhi laju reaksi. Sehingga LKPD yang dikembangkan sudah sesuai dengan fungsinya yakni sebagai bahan ajar yang memudahkan siswa dalam memahami materi yang diberikan (Prastowo 2011).

Kelayakan konten LKPD juga mencakup $80 \%$ proporsi mengikuti model pembelajaran inkuiri terbimbing. Model pembelajaran inkuiri adalah proses pendefinisian dan penelitian masalah, pengajuan hipotesis, perancangan percobaan, pengolahan data dan penarikan kesimpulan tentang masalah(Arends 2012). Dalam proses pengolahan data terdapat komponen keterampilan pengorganisasian berupapenyajian data pada tabel kemudian mengubahnya dalam bentuk grafik. Komponen ini merupakan salah satu komponen nested. Sesuai harapan, peserta didik mampu mengolah dan menginterpretasikan data, khususnya organisasi (Permendikbud 2012).

Dalam kriteria kebahasaan mendapatkan presentase $\geq 61 \%$ yakni $90,7 \%$ dalam kategori sangat valid. Bahasa yang terdapat dalam LKPD menghubungkan informasi atau materi pembelajaran yang diperoleh melalui penemuan dengan istilah yang mudah dipahami. Hal ini sesuai dengan struktur kognitif Piaget yang menunjukkan bahwa anak-anak usia 16-18 tahun berada pada tahap operasi formal, sehingga mereka dapat bernalar dan memahami makna abstrak dan prinsip-prinsip dasar teoritis, serta mengembangkan pemikiran reflektif mereka dalam pemecahan masalah(Santrok 2014).

Komponen penyajian materi meungkinkan peserta didik dalam belajar melaluisumbersumber yang ada menghasilkan kelayakan 
tertinggi yakni89,2\% dengan kriteria sangat layak. Pelaksanaan proses pembelajaran dengan LKPD yang sedang dikembangkan, peserta didik melakukan perumusan masalah, merumuskan hipotesis sesuai dengan sumber buku yang disediakan, menentukan variabel, melakukan penelitian dengan arahan guru, hingga membuat kesimpulan. Hal ini didasarkan pada pentingnya pembinaan keterampilan proses sains (KPS)peserta didik, yaitu dalam proses pembelajaran pengembangan konsep tidak lepas dari pengembangan sikap dan nilai anak(Semiawan 1990). Selain itu, sebelum merumuskan hipotesis dan melakukan analisis data tersedia link dalam LKPD yang berisi sumber buku atau referensi. Tujuannya untuk mendorong peserta didik membaca lebih jauh sehingga memiliki pemahan konsep yang lebih kuat tentang materi itu (Depdiknas 2008).

Validasi LKPD berdasarkan kriteria kegrafikan menunjukkan kriteria sangat layak dengan presentase $90,7 \%$. Terdapat aspek cover yang menarik, kesesuaian warna dengan background, serta istilah dan simbol dalam rumus dinyatakan dengan jelas. LKPD dirancang dengan pembelajaran online sehingga desain dengan warna, animasi dan cover yang menarik dapat membangkitkan minat belajar. Istilah dan simbol dalam rumus dinyatakan dengan konsisten, membuat peserta didik nyaman saat LKPD digunakandan membuat fokus tidak terpecah. Selaras dengan hasil respon peserta didik pada komponen kegrafikan dengan presentase $100 \%$.

\section{Kepraktisan LKPD}

Kepraktisan LKPD yang dikembangkan diukur melalui angket respon dan aktivitas.Angket respon diberikan kepada 15 siswa setelah mengikuti uji coba terbatas LKPD. Aktivitas peserta didik diamati oleh tiga mahasiswa kimia. Respon peserta didik menghasilkan presen rata-rata yang disajikan dalam tabel 8 .

Tabel 8. Hasil Angket Respon Peserta Didik

\begin{tabular}{lll}
\hline $\begin{array}{c}\text { Kriteria } \\
\text { yang Dinilai }\end{array}$ & $\begin{array}{c}\text { Presentase } \\
\text { Rata-rata }\end{array}$ & \multicolumn{1}{c}{ Kategori } \\
\hline Isi & $94 \%$ & Sangat merespon \\
Kebahasaan & $94 \%$ & Sangat merespon \\
Penyajian & $88 \%$ & Sangat merespon \\
Kegrafikan & $100 \%$ & Sangat merespon \\
\hline
\end{tabular}

Berdasarkan hasil respon peserta didik, setiap komponen telah mencapai presentase $\geq 61 \%$ yang berarti bahwa LKPD sudah memenuhi kriteria kepraktisan. Pressentase yang diperoleh pada rentan 88\%-100\% dalam kategori sangat merespon. Selaras dengan hasil observasi aktivitas peserta didik yang relevan dengan presentase $93,3 \%$. Tidak ada pembelajaran tanpa kegiatan atau aktivitas belajar siswa.

Pada aspek "LKPD dapat membangkitkan motivasi peserta didik dalam mempelajari materi laju reaksi" yang terdapat pada kriteria penyajian memperoleh presentase respon $100 \%$. Hal tersebut berarti LKPD telah berfungsi bahan ajar yang bisa memfasilitasi peserta didik jauh lebih aktif dengan pendampingan guru (Prastowo 2011). Hal tersebut selaras dengan hasil validitas kriteria penyajian sebesar 90,7\% dalam kategori sangat valid.

\section{Keefektifan LKPD}

Keefektifan LKPD yang sedang dikembagkan dapat dilihat dari nilai n-gain hasil belajar pada tes KPS saat pembelajaran. Tes yang dilakukan meliputipretest dan posttest yang berisi soal uraian sesuai dengan indikator KPS, meliputi perumusan masalah, perumusan hipotesis, identifikasi variabel percobaan, penyajian data, analisis data, dan membuat kesimpulan(Arends 2012).

Berdasarkan hasil pre-test yang diperoleh, semua komponen tidak lengkap. Hal tersebut dapat terjadi karenaketerampilan proses sains kurang dilatihkan terutama pada pembelajaran kimia. Setelah dilatihkan LKPD berbasis inkuiri terbimbing berpendekatan nested untuk melatihkan keterampilan proses sains siswamateri laju reaksi, hasil posttest peserta didik rata-rata tuntas. Presentase rata-rata hasil posttest disajikan dalam Tabel 9.

Tabel 9. Data Hasil Postetst

\begin{tabular}{lcl}
\hline \multicolumn{1}{c}{ Komponen } & $\begin{array}{r}\text { Total } \\
\text { Skor }\end{array}$ & Kriteria \\
\hline Merumuskan masalah & $95 \%$ & Sangat tinggi \\
Hipotesis & $98 \%$ & Sangat tinggi \\
Identifikasi variabel & $93 \%$ & Sangat tinggi \\
Menyajikan data & $95 \%$ & Sangat tinggi \\
Analisis data & $84 \%$ & Sangat tinggi \\
Kesimpulan & $86 \%$ & Sangat tinggi \\
\hline
\end{tabular}

Dari hasil yang diperoleh, komponen penyajian data dalam bentuk tabel memiliki proporsi data tertinggi yaitu persentase keterampilan proses sains siswa tertinggi. Penyajian data bentuk tabel juga diinterpretasikan ke dalam grafik. Hal tersebut dikarenakan peserta didik sudah pernah mempelajarinya pada mata pelajaran matematika, 


\section{Chemistry Education Practice, 4 (2), 2021 - 159}

Isnaini, Yonata

sehingga pada LKPD terdapat materi untuk membantu peserta didik dalam meningatnya kemudian menerapkan pada keterampilan proses sains(Yulita 2020). Sedangkan komponen terendah terdapat pada komponen analisis data. Hal ini disebabkan oleh kurangnya keahlian peserta didik dalam mengaitkan data percobaan yang didapat dengan materi laju reaksi yang dipelajari lebih mendalam lagi. Namun, peserta didik telah menbahas analisis sesuai dengan hipotesis.

Seacara keseluruhan hasil belajar KPSpeserta didik, diperoleh hasil bahwa pengembangan LKPD telah memenuhi kriteria keefektifan yang dilihat dari n-gain rata-rata yang diperoleh yakni 0,84 dengan kategori tinggi. Hal itu selaras dengan hasil tes pengetahuan peserta didik memperoleh nilai rata-rata 85 yang telah memenuhi standar ketuntantasan sekolah (KKM).

\section{SIMPULAN}

Berdasarkan kesesuaian antara hasil penelitian dengan pertanyaan yang diajukan, dapat disimpulkan bahwa LPKD yang dikembangkan tergolong sangat layak digunakan sebagai media pembelajaran menurut aspek kriteria isi, penyajian, kebahasaan dan kegrafisan dengan presentase $86 \%-90,7 \%$. Selain itu, LKPD yang dikembangkan praktis untuk digunakan. Hal tersebut dibuktikan dengan aktivitas peserta didik yang relevan menghasilakn presentase 93,3\% serta respon dengan kategori sangat merespon dengan kriteria isi, penyajian, kebahasaan dan kegrafisan menghasilkan presentase 94\%-100\%. Selain itu, LKPD telah efektif digunakan karena sudah memenuhi kriteria keefektifan yang dilihat dari nilai rata-rata $\mathrm{n}$-gain KPS peserta didik yang diperoleh yakni 0,84 dalam kategori tinggi. Hal itu selaras dengan hasil tes pengetahuan siswa yang menghasilkan nilai rata-rata 85 yang telah memenuhi standar ketuntantasan sekolah (KKM)

\section{DAFTAR PUSTAKA}

Aftriani, D. N., Muntari, M., Haris, M., \& Anwar, Y. A. S. (2019). Pengaruh pembelajaran inkuiri terbimbing pada pelajaran kimia terhadap kemampuan berpikir kreatif siswa Kelas XI IPA SMAN 2 Mataram. Chemistry education practice, 1(2), 1-6.

Arends, I. R. 2012. Learning to Teach 9th Ed. New York: Mc Graw Hill.

Ariani, S., Effendy, E., \& Suharti, S. (2020).
Model Mental Mahasiswa Pada Fenomena Penghilangan Karat Melalui Elektrolisis.

Chemistry Education Practice, 3(2), 55-62. BNSP. 2010. Paradigma Pendidikan Abad XXI. Jakarta: BNSP.

Depdiknas. 2008. Panduan Pengembangan

Bahan Ajar. Jakarta: Direktorat Pembinaan

Sekolah Menengah Atas Direktorat

Jenderal Manajemen Pendidikan Dasar dan Menengah Departemen Pendidikan

Nasional.

Fogarty, Robin. 1991. The Mindful School: How to Integrate The Curricula. Palatine: IRI/Skylight Publishing.

Mulyasa. 2011. Menjadi Guru Profesional. Bandung: PT Remaja Rosdakarya.

Permendikbud. 2012. Peraturan Menteri Pendidikan Dan Kebudayaan Republik Indonesia Tentang Kerangka Dasar Dan Struktur Kurikulum Sekolah Menengah Kejuruan/Madrasah Aliyah Kejuruan. Jakarta: Kementrian Pendidikan dan Kebudayaan.

Permendikbud. 2020. Regulation of the Minister of Education Number 719: KI Dan KD Esensial. Kementerian Pendidikan dan Kebudayaan Indonesia.

Prastowo, Andi. 2011. 53 Journal of Chemical Information and Modeling Panduan Kreatif Membuat Bahan Ajar Inovatif. Yogyakarta: DIVA Press.

Riduwan. 2013. Skala Pengukuran VariabelVariabel Penelitian. Bandung: Alfabeta Bandung.

Rustaman, N. 2005. Strategi Belajar Mengajar Biologi. Malang: UM Press.

Sanjaya, Wina. 2012. Strategi Pembelajaran Berorientasi Standar Proses Pendidikan. Jakarta: Kencana Prenadamedia Group.

Santrok, John W. 2014. Psikologi Pendidikan Edisi5. Jakarta: Salemba Humanika.

Semiawan, Conny. 1990. Pendekatan Keterampilan Proses.Jakarta:Gramedia.

Sudarwan, Danim. 2013. Perkembangan Peserta Didik. Bandung: Alfabeta Bandung.

Trianto. 2012. Model Pembelajaran Terpadu. Jakarta: Bumi Aksara.

Yulita, R. (2020). Penerapan Model Pembelajaran Inkuiri Terbimbing untuk Melatihkan Keterampilan Berpikir Kritis Peserta Didik Pada Materi Asam Basa Kelas XI SMAN 3 Lamongan. UNESA Journal of Chemical Education, 9(2). 